\title{
EN TORNO A FLOR DE SANTIDAD, NOVELA POEMÁTICA DE VALLE-INCLÁN
}

\author{
ROCÍO CHARQUES GÁMEZ
}

Université de Pau

\section{RESUMEN}

Este artículo es una aproximación al carácter simbólico de Flor de santidad (1904), de Ramón María del Valle-Inclán. Con él se pretende, además, poner de relieve la importancia de este texto como ejemplo de prosa poética. Otro aspecto analizado es el de las posibilidades interpretativas del libro, teniendo en cuenta el tratado de estética escrito por el autor en 1916, La lámpara maravillosa.

Palabras clave: Ramón del Valle-Inclán. Simbolismo. Prosa poética.

\section{ABSTRACT}

This article is an approach to the symbolism in Flor de Santidad (1904), by Ramón María del Valle-Inclán. We also want to show the relevance that this text has as an example of poetic prose. Another point analyzed refers to the different possibilities of interpretation having in mind his treatise written in 1916, La lámpara maravillosa. Key words: Ramón del Valle-Inclán. Symbolism. Poetic prose.

Flor de santidad. Historia milenaria es la obra que Valle-Inclán publica en 1904, cuya gestación se remonta a una serie de narraciones aparecidas en prensa años atrás. La transformación y empleo de estos pre-textos en el texto han sido ampliamente estudiados por críticos como Éliane Lavaud (1991), quien observa el modo en que se insertan y modifican estos fragmentos, y cómo conforman, en última instancia, una unidad ${ }^{1}$. Asimismo cabe notar la

1. Respecto a la utilización de los pre-textos en Flor de santidad resulta esclarecedora la aclaración de Arcadio López-Casanova (2006, págs. 14-15), que percibe el rastro de estas narraciones a lo largo de todo el libro, pero, sobre todo, en las estancias primera 
corrección que Valle-Inclán efectúa en las distintas ediciones de su obra (1913 y 1920), un rasgo este, el de realizar alguna variación en sus textos, como se sabe, propio del autor.

El interés que despierta este libro es indudable, no solo por el magistral proceso de elaboración en el que se ve envuelto, sino también porque ha llevado a la crítica a formular varias hipótesis interpretativas. Pero, por encima de todas estas interpretaciones sobre la significación última de la obra, se yergue la majestuosidad del uso del lenguaje que Valle-Inclán realiza y a la que todos los autores han hecho referencia a la hora de analizar estas páginas. El escritor, en una carta a Torcuato Ulloa fechada el 27 de agosto de 1904 en Aranjuez, expone cómo venía trabajando en esta novela desde hacía diez años y declara: «es la única vez que estoy un poco satisfecho de mi obra» (Hormigón, 2006, págs. 70-71).

A continuación, nos proponemos revisar estas interpretaciones y aportar la impresión que surgió de nuestra lectura. Qué mejor impresión con la que abrir esta somera recopilación interpretativa que el recuerdo del soneto de Antonio Machado que encabeza la obra:

Esta leyenda en sabio romance campesino,

Ni arcaico ni moderno, por Valle-Inclán escrita,

Revela en los halagos de un viento vespertino,

La santa flor del alma que nunca se marchita.

Es la leyenda de campo y campo. Un peregrino

Que vuelve solitario de la sagrada tierra

Donde Jesús morara, camina sin camino

Entre los agrios montes de la galaica sierra.

Hilando silenciosa, la rueca a la cintura,

Ádega, en cuyos ojos la llama azul fulgura

De la piedad humilde, en el romero ha visto,

Al declinar la tarde, la pálida figura,

La frente gloriosa de luz y la amargura

De amor que tuvo un día el SALVADOR DOM. CRISTO.

y cuarta. López-Casanova articula en cuatro bloques de tematización las once narraciones a las que hacemos referencia. El primero es el más importante pues a él se deben los signos de protagonización y de él recoge el título de la obra y su subtítulo, Historia milenaria. Estas narraciones son Ádega. Cuento bizantino (Germinal, 1897), Ádega. Historia milenaria (Revista Nueva, 1899), Ádega. Historia milenaria (Electra, 1901) y Flor de santidad (Los Lunes de El Imparcial, 1901). El segundo grupo lo conforman los textos Lluvia (Almanaque de Don Quijote, 1897) y Año de hambre. Recuerdo infantil (Heraldo de Madrid, 1903) que aportan la localización temporal de la historia. El siguiente grupo ofrece información sobre la organización social y la visión del mundo del mundo gallego: ¡Malcopado! (El Liberal, 1902) y Geórgicas (Los Lunes de El Imparcial, 1904). Los tres relatos del último grupo descubren el imaginario mítico gallego: Égloga, Un cuento de pastores y Santa Baya de Cristamilde (los tres publicados en Los Lunes de El Imparcial, en 1902 el primero y en 1904 los otros dos). 
La historia, como el subtítulo reza, es una historia milenaria, y, como veremos, el tiempo en ella es una de las claves principales en las que se basa su estructura y lenguaje. La flor de santidad se refiere a la humilde pastora que ve en el peregrino a Nuestro Señor. El argumento puede exponerse en unas pocas líneas. Ádega es una inocente pastora que pierde a sus padres y que vive en una venta donde no recibe ningún tipo de afecto. El peregrino buscando posada pone de relieve la falta de caridad de los venteros, en contraposición a Ádega que lo recibe creyendo ver en él a Cristo. Esta lo acoge en el establo donde duerme y él aprovecha su veneración para saciar su apetito carnal. El peregrino maldice el rebaño de los dueños de la venta y el hijo de la ventera asesina al mendicante. Esta muerte provoca que Ádega abandone la venta enajenada y que vaya relatando sus visiones sobre la naturaleza divina del hijo que cree que espera. Finalmente la acogen en el Pazo de Brandeso donde advierten que sufre el mal cativo y la acompañan a la misa de las endemoniadas, donde se descubre que posiblemente esté embarazada.

El descubrimiento final del embarazo de la pastora ha llevado a algunos críticos a interpretar que el objetivo de la obra es una censura a la Anunciación de María o a la credulidad y superstición del pueblo gallego. Otros, en cambio, destacan el simbolismo del libro, el carácter místico y anacrónico de la historia relatada, que lo emparenta con La lámpara maravillosa (1916). Los primeros lectores de 1904 apuntan ya los enfoques que posteriormente se han ido desarrollando (Dougherty, 1997, págs. 341-354). Bernardo G. de Candamo es el primero en apreciar la nota irónica en Flor de santidad en su reseña aparecida en El Gráfico el 4 de noviembre del año de la primera edición. Este mismo año, un día antes, en El Liberal, José Nogales señala el sincretismo de varios componentes: la protagonista evoca la fe católica y se encuadra entre dos tradiciones, la realista y la pagana céltica. Esta variedad compositiva también la anota Gómez Carrillo en las páginas de Mercure France, en diciembre de 1904. Debido a las múltiples interpretaciones, Dru Dougherty (1997, pág. 348) concluye que Flor de santidad ensambla tres tipos de discurso, sin que ninguno tenga hegemonía sobre los otros. Estos son el discurso pagano, pues en el texto hay muchas referencias a las églogas virgilianas y a las creencias célticas; el discurso cristiano, ya que es indudable el eco de la historia de la Anunciación y de leyendas piadosas; y el de las formas canónicas del XIX, es decir, el realismo y el costumbrismo.

Ante esta doble interpretación, Rosa Alicia Ramos (1991, págs. 171-204) expone el carácter indefinido de esta historia, que presenta rasgos típicos de la fabulate, el memórate y la anti-leyenda, sin que pueda decidirse por uno de estos subgéneros de la leyenda a la hora de definir Flor de santidad. Esta 
indefinición es la que lleva a la multiplicidad de puntos de vista que hemos apuntado. El principio del libro, sobre todo la primera estancia, es el que mejor responde a los rasgos de la fabulate porque en un tiempo remoto indeterminado ocurren sucesos en los que parece haber una intervención divina. Es el momento en el que la atención se focaliza en la visión idealizada de Ádega. En el memórate también tienen lugar sucesos insólitos pero sin intervención sobrenatural y, asimismo, la acción sucede en un pasado próximo y en un lugar localizable. Los presagios de muerte son asunto recurrente en él, así como las maldiciones. Son las tres estancias centrales las que más se aproximan a la definición de este subgénero. Recordemos cómo la pastora tiene un sueño premonitorio de la muerte del peregrino. No obstante, Rosa Alicia Ramos confirma que el texto se aleja de este subgénero porque

[...] da indicaciones de que la situación existencial de Ádega y su deficiencia intelectual son la causa fundamental de sus nociones equivocadas, siendo el peregrino el mero catalizador de la conducta que exterioriza dichas ideas. Estas explicaciones racionalistas -aunque sutiles- de la vida de Ádega rompen con el estilo intuitivo que caracteriza el memórate, acercándose más a la desvalorización de ocurrencias enigmáticas propia de la anti-leyenda (pág. 192).

Tampoco se decanta por la anti-leyenda, porque a pesar de que, como sucede en esta, la historia se plantea como memórate hasta casi el final cuando se descubre la realidad, no existe un tono de mofa en los personajes que advierten la situación y tampoco el lector se siente superior a la pastora. Como el narrador elegido es la tercera persona que no interviene en la acción, Rosa Alicia Ramos afirma que los rasgos de los tres subgéneros se entremezclan y que la preponderancia de uno sobre los demás depende más del punto de vista del lector que del narrador.

Durante nuestra lectura no hemos percibido, al igual que Rosa Alicia Ramos, ninguna nota que permita interpretar Flor de santidad como una antileyenda, por lo que no compartimos las interpretaciones que presentan la obra como alegato contra la falsa religiosidad o la credulidad popular. Las palabras finales de la novela no son aquellas que pronuncia la dueña al indicar el posible embarazo de Ádega, sino que se dedican al sonido de las viejas campanas que se oye al fondo del valle. Este canto de las campanas viene enmarcado entre la tradición cristiana («cantan [...] las glorias celestiales», pág. 154) y la céltica («contemplan el vuelo de brujas y trasgos», pág. 154). Por nuestra parte, observamos una clara finalidad artística, más que ideológica, en esta obra, donde, como ya han indicado numerosos críticos, se percibe el carácter musical y pictórico de la escritura. La misma disposición de la obra, estructurada simétricamente en estancias, demuestra el especial cuidado del autor por 
la forma. Sin embargo, conviene apuntar que existen ciertas notas que enlazan Flor de santidad con el tratado de estética de Valle-Inclán titulado La lámpara maravillosa, como estudiaremos más adelante.

La cuestión del tiempo ${ }^{2}$ es uno de los pilares fundamentales, o quizá el pilar básico, de esta novela poemática. El subtítulo (Historia milenaria) ya es una declaración de intenciones. El predominio del empleo del demostrativo «aquel» también apunta a una indefinición y lejanía, que se subraya, además, con el juego de tiempos verbales que busca esta ambientación anacrónica. A pesar de la actualidad en la época de Valle-Inclán de ciertos ritos, como la misa de las endemoniadas, referentes históricos, como el año del hambre, o historias, como la búsqueda de tesoros en Galicia reactivada por las joyas descubiertas en los castros (Lavaud, 1991, págs. 394-402) a los que se menciona en el libro; es indudable que el aire que envuelve al relato no pertenece al presente sino a un vago pasado.

Esta historia milenaria está enmarcada en la Galicia rural, con personajes muchas veces indefinidos, es decir, sin nombres y sin rasgos descriptivos definitorios pero que representan a personas que habitan esos lares. La representación de este mundo no proviene de la visión directa del mismo, sino de la memoria del autor. A través del recuerdo de Galicia, surge una Galicia propia, personal, que es la que puebla su obra literaria. A estos recuerdos se suman los de las historias oídas desde su niñez, historias que se transmiten oralmente y que plasman la mitología de un pueblo. En Flor de santidad está muy presente la importancia de la figura del transmisor oral de historias. Este tipo de transmisión cultural hace referencia al saber antiguo, milenario, el que pasa de las generaciones antiguas a las nuevas y que se perpetúa eternamente. Veamos unos cuantos ejemplos ilustrativos. El peregrino es «uno de esos peregrinos que van en romería a todos los santuarios y recorren los caminos salmodiando una historia sombría, forjada con reminiscencias de otras cien» (pág. 77). Los personajes hablan entre sí con un halo de misterio, de leyenda. Así, cuando las mujeres comentan que Ádega padece el mal cativo, «su coloquio parece tener el misterio de un cuento de brujas» (pág. 119). El viejo que relata la historia de la reina mora como si realmente él se hubiera encontrado con ella, utiliza una «entonación lenta y religiosa, de narrador milenario» (pág. 121). Junto a estos rasgos de narradores antiguos que se reparten en toda la obra, los personajes y la ambientación de la historia también poseen

2. «Más que cualquier aspecto aislado de Flor de santidad, es su fundamental unidad de tono, ambiente y concepción temporal -sugerencia de la unidad y la armonía cósmicas- lo que relaciona la novela con la estética simbolista, sobre todo con el quietismo estético que es el núcleo de La lámpara maravillosa» (Risley, 1992, págs. 86-87). 
caracteres literarios, bien de leyendas hagiográficas, bien de mitología clásica o céltica. Ádega «parecía la zagala de las leyendas piadosas» (pág. 79) y tenía «un hermoso nombre antiguo» ${ }^{3}$ (pág. 79), hablaba en «el romance arcaico, casi visigodo, de la montaña» (pág. 80). Muchos personajes son el calco de otros legendarios, como el viejo ciego ${ }^{4}$ que narra historias y que parece un fauno rodeado de ninfas, un «dios primitivo, aldeano y jovial» (pág. 95). Las ovejas también emiten «un dulce balido como en las viejas églogas» (pág. 96). Cuando las endemoniadas descubren sus cuerpos para recibir las olas purificadoras, se dice que «su desnudez surge como un gran pecado legendario» (pág. 151). Como declara Valle-Inclán en la carta dirigida a Torcuato Ulloa citada con anterioridad: «Más que a los libros de hoy, se parece a los libros de la Biblia: otras veces es homérica, y otras gaélica» (pág. 71). Y esta visión se entremezcla, estos personajes habitan un mismo mundo y se comunican entre sí.

En el texto «Una visita al convento de Gondarín» (1987, pág. 118) que Valle-Inclán escribe para El Globo (22 de septiembre de 1891), traza una evocación que le viene a la memoria de las ruinas de este convento al que rememora como en un ensueño y a las que compara con las de la antigua Grecia. Es fácil advertir la interrelación establecida entre ambas culturas, aparte de sumar los rastros de ritos celtas encontrados cerca del altar cristiano. Además del canto a las ruinas, típico del hombre romántico ${ }^{5}$, se anota cómo las mujeres con el mal cativo acuden a la fuente milagrosa que hay allí. Otro elemento que relaciona estas páginas con Flor de santidad es la descripción del retablo, en donde se encuentra un Cristo bizantino. El relato se cierra con un adiós que nos remite al final de la novela en la primera edición ${ }^{6}$.

3. En la Sonata de otoño, de ambiente gallego, se comenta la estilización del nombre Águeda, del que surge Ádega, «hermoso nombre antiguo». En Mi bisabuelo (Jardín Umbrío) Águeda del Monte representa la rebeldía de los campesinos de Galicia, y en la novela de mocedad El gran obstáculo, la protagonista se llama también Águeda (Díaz-Plaja, 1965, pág. 178).

4. Roberta L. Salper (1988) estudia la aparición de este personaje en la obra literaria de Valle-Inclán y las funciones que cumple en ella. La introducción de Electus, el Ciego de Gondar, se hace en la novela que estudiamos y, más tarde, aparece en El Marqués de Bradomín (1097), Romance de lobos (1908), Los cruzados de la causa (1908), El embrujado (1913), Divinas palabras (1920) y Cara de Plata (1923).

5. $\mathrm{M}^{\mathrm{a}}$ Paz Díez Taboada (1995) realiza un estudio comparativo en el que extrae los elementos de novelas románticas que Valle-Inclán utiliza en Flor de santidad.

6. Eliane Lavaud (págs. 173-174) admite que la supresión de esta palabra lleva a cambiar la lectura del libro, porque si no desaparece, rechaza la posibilidad de que ese mundo, que se contrapone a la sociedad actual (cuyos valores son el dinero, lo material y la razón), pueda existir. 
En los textos periodísticos del autor podemos entrever otros paralelismos con Flor de santidad. La historia de la princesa mora encantada a la que se remite en varias ocasiones en la novela, es mencionada en «Cartas galicianas. Por la tierra saliniense. El castillo de Lobeira» (El Globo, 4 de noviembre de 1891). En él, Valle-Inclán habla de una joven aldeana que le contaba estas historias. «Lumbres de mi hogar», que aparece después de que se publique la novela, en Europa (6 de marzo de 1910), es un texto muy interesante porque presenta ideas enlazadas con Flor de santidad y La lámpara maravillosa, como la idea de la flor de amor, o las rosas y la sangre (emparentando, de esta forma, la rosa del amor y la rosa del dolor), así como el peregrino con tres conchas en la esclavina y rosario al cuello al que se le da posada.

Las «Notas de la Exposición de Bellas Artes de 1912», publicadas en Nuevo Mundo, se han citado constantemente en los trabajos acerca de La lámpara maravillosa. En lo que respecta a la novela de 1904 conviene recordarlas por los puntos en común que comparten. Al hablar de Romero de Torres (30 de mayo de 1912), se advierte su admiración por el pintor que ha logrado captar en una imagen «una alusión cargada de significados» (1987, pág. 258). «El artista, como el místico, ha de tener percepciones más allá del límite que marcan los ojos y los oídos, entrever en la ficción del momento el gesto en que todas las cosas se inmovilizan como en un éxtasis» (pág. 257). En Flor de santidad hay una gran carga pictórica. Las acciones se suelen presentar en cuadros y normalmente los personajes aparecen relacionados siempre a ciertos gestos o actividades, van acompañados de los mismos o similares adjetivos en su presentación $^{7}$, con la finalidad de dejarlos fijados en un movimiento único que los define y que, a su vez, los deja fuera del tiempo. Eliane y Jean-Marie Lavaud explican esto mismo: "Cette répétition de microséquences textuelles, très valle-inclanienne, est, certes, une façon d'annuler le temps, de faire surgir, comme dans l'humanité archaïque, un temps sacré qui se répète de façon cyclique» (1991, pág. 52). Los ojos de Ádega son siempre violetas en las que se reflejan sus sentimientos, normalmente sus arrobos místicos, y su imagen representativa es aquella en la que aparece sentada hilando con su rueca en la cintura. El sonido de las campanas va acompañando el relato y estas son «piadosas, madrugadoras, sencillas como dos viejas centenarias» (pág. 103), también son «piadosas, madrugadoras, sencillas como dos abadesas centenarias» (pág. 122). Con ese sonido de campanas, que puebla toda la historia,

7. Allen W. Phillips (1970, págs. 164-166) enumera algunas de estas reiteraciones: «No sólo le interesa a Valle fijar y casi inmovilizar a Ádega en un gesto definitivo o en su postura eterna, sino que también al embellecer su casta y hermosa figura casi siempre se vale de las mismas imágenes descriptivas» (pág. 164).

Anales, 22, 2010, pp. 49-63 
recordemos que se cierra el relato. Se podrían citar muchos más ejemplos, pero no pretendemos realizar una lista pormenorizada de ellos, sino ofrecer algunos representativos. Valle-Inclán repite, a lo largo de la historia, palabras que indican un rasgo definitorio de un personaje, animado o inanimado, de la narración, y con ello consigue dejar fijada su visión en el tiempo, logra eternizarlo.

Este carácter anacrónico, fuera del tiempo, de la historia se realiza mediante la presentación de personajes con peculiaridades que los hacen atemporales, así como espacios en los que se aprecia esta misma característica. La filiación entre Flor de santidad y La lámpara maravillosa es incuestionable por la clara identificación de muchas ideas plasmadas en la poética de Valle-Inclán. La descripción de la experiencia mística de Ádega en el capítulo quinto de la primera estancia comparte muchas de las recogidas en La lámpara maravillosa. En ella se habla de la desconexión temporal de la pastora que le permite estas visiones. También personajes como el abuelo que cuenta historias, se relacionan, a su vez, con las anotaciones del texto de La lámpara maravillosa. La idea del agua como «místico cristal» (p. 103) es otro de los símbolos de este libro. La belleza de los cristales reside en que simbolizan la eternidad:

De todas las cosas bellas para los ojos, ninguna tanto como los cristales. El goce de los ojos al mirarlos es un sentimiento sagrado, porque para los ojos los cristales no tienen edad. Cuando pensamos que su ayer es de mil años y que permanecerán sin mudanza al cumplirse otros mil, sentimos la emoción religiosa de considerarlos fuera del Tiempo. La luz de los cristales tiene algo de oración (1995, pág. 81).

En el tratado de estética, Valle-Inclán describe Santiago de Compostela como una ciudad eterna, en ella «la oración de mil años renace en el tañido de sus cien campanas [...] Compostela, inmovilizada en el éxtasis de los peregrinos, junta todas sus piedras en una sola evocación, y la cadena de los siglos tuvo siempre en sus ecos la misma resonancia» (1995, págs. 139-140). Este sonido de campanas puebla las páginas de Flor de santidad, y el carácter eterno de esos montes gallegos se remarca cuando se apunta a las «piedras célticas, doradas por líquenes milenarios» (pág. 79). El peregrino se presenta como si fuera aquellos que iban por el Camino de Santiago, ruta «que la sandalia del peregrino iba labrando piadosa en el polvo de la tierra» (pág.77). Cuando el escritor evoca en La lámpara maravillosa su primera intuición literaria, recuerda a su madrina leyendo un libro piadoso. En este pasaje se congela la imagen de la madrina como en un cuadro, en un instante que encierra todos los instantes, eterno y anacrónico. En estas líneas se puede descubrir el momento en que se capta una imagen porque en ella se recoge la esencia de la 
madrina y, a su vez, se encarna en ella la sustancia de las leyendas piadosas y cuentos de princesas que ella le narra. Estos elementos (leyendas piadosas, cuentos de princesas, acción paralizada, emoción estética y mística) se encuentran también en Flor de santidad'.

Uno de los momentos de Flor de santidad que podemos evocar en donde se percibe claramente otra de las ideas del tratado mencionado, es la visión de la señora del Pazo de Brandeso hilando en la oscuridad. Ese cuadro se vincula con la imagen de una época anterior, más cristiana, y se realza la idea de la armonía cósmica, uno de los conceptos clave del texto de 1916:

Tras los cristales del balcón, todavía hilaba la señora, con las últimas luces del crepúsculo. Y aquella sombra encorvada, hilando en la oscuridad, estaba llena de misterio. En torno suyo todas las cosas parecían adquirir el sentido de una profecía. El huso de palo santo temblaba en el hilo que torcían sus dedos, como temblaban sus viejos días en el hilo de la vida. La Mayorazga del Pazo era una evocación de otra edad, de otro sentido familiar y cristiano, de otra relación con los cuidados del mundo. Había salido la luna, y su luz bañaba el jardín, consoladora y blanca como un don eucarístico. Las voces de las espadadoras se juntaban en una palpitación armónica con el rumor de las fuentes y de las arboledas. Era como una oración de todas las criaturas en la gran pauta del Universo (pág. 146).

En el plano de los paralelismos y simetrías, que podríamos enlazar con las repeticiones de las descripciones, debemos hacer referencia a la estructura de Flor de santidad. La obra se compone de cinco estancias de cinco capítulos cada una, excepto la tercera que tiene seis. Esta estructura permite dividir el relato en dos partes: estancias primera y segunda y tres primeros capítulos de la estancia tercera; y tres últimos capítulos de la estancia tercera junto a las estancias cuarta y quinta. La construcción está tan meditada que en el centro se sitúa la muerte del peregrino. Eliane Lavaud (1991, págs. 364-368) advierte, a su vez, paralelismos temáticos entre los distintos capítulos que aportan resonancias armónicas. López-Casanova (2006, pág. 39) apunta, por su parte,

8. El fragmento de La lámpara maravillosa al que hacemos referencia es el siguiente: «Al final del camino de cipreses, en la escalinata de piedra, estaba sentada mi Madrina. Leía bajo un vuelo de palomas con el libro devoto abierto en la falda. Aún recuerdo cómo me sentí penetrado de la gracia de su mirar ideal y cándido. Aún evoco y revivo en mí la emoción sagrada. Otras muchas veces había visto a mi Madrina en igual actitud, al término del camino de cipreses que se juntaban en una sucesión de pórticos, y solamente en aquella tarde de leyenda piadosa gusté tan inefable alegría al contemplarla. Bajo la sombra de los viejos cipreses, mi alma de niño enlazaba la emoción estética y la emoción mística, como se enlazan en la gracia de la rosa color y fragancia. Acaso fue aquella mi primera intuición literaria: Yo había llegado a encarnar en la sustancia de la vida y en sus sombras más bellas las historias piadosas y los cuentos de princesas que me contaba mi Madrina» (1995, pág. 150).

Anales, 22, 2010, pp. 49-63 
la simbología numérica de esta estructura. El cinco es el número nupcial, el de la armonía, el de la fusión de lo terrestre y lo celeste. En cambio, el seis es el número de la tensión entre el bien y el mal, el de los antagonismos. Si se suman los capítulos que componen cada parte: $5+5+3 / / 3+5+5$ nos da como resultado el número trece, número negativo que «marca una evolución fatal hacia la muerte, hacia el acabamiento de toda fuerza, o, también, de esfuerzo periódicamente truncado» (pág. 39). En lo que respecta a la numerología, cabe añadir que siete son las olas que han de romper contra las endemoniadas para acabar con su posesión en la misa que comienza a partir de las doce de la noche. Son siete «como los pecados del mundo» (pág.152).

Flor de santidad es un texto cargado de simbología. En el centro de la obra se sitúa la muerte del peregrino, pero esta muerte la presiente Ádega en uno de sus sueños, así como tiene una visión premonitoria de su maternidad (último capítulo de la tercera estancia). En este punto, además, se juntan dos signos opuestos pero que van aparejados: Vida/Muerte. La vida es el anuncio del nuevo ser que va a nacer y la muerte es, precisamente, la del padre de la criatura. Esta conjunción de vida y muerte aparece justo en la estancia central de la obra, la muerte, específicamente, en el centro. Algunos críticos incluyen también la muerte de los padres a la que se hace referencia al principio del relato a la hora de explicar este eje temático de Flor de santidad.

Los símbolos ${ }^{9}$ que remiten a la futura muerte del peregrino son varios. En el capítulo tres de la tercera estancia, Ádega regresa a la venta cargando con el peso de un corderillo que ha enfermado por el mal de ojo. En este mismo capítulo hay otro personaje que carga con otro animal muerto que es la contraposición al cordero. Se trata del lobo, animal al que se temía por sus ataques y que entra a formar parte de las historias terroríficas que se narran en Galicia. Pero, a su vez, en Flor de santidad la presencia del lobo viene, en muchos casos, emparejada a la del peregrino. Se puede advertir, a su vez, el juego del Bien y el Mal por estos animales: el cordero y el lobo. Por tanto, esta podría ser una pista que abre los signos que se refieren a la muerte del peregrino. Además este mozo explica a la ventera que el rebaño de su amo también estaba embrujado y que acabó con el maleficio al entregarle una carga de trigo al autor del embrujo. La forma de reconocerlo fue quemando en una hoguera a la res más enferma, pues a los balidos de esta acudió el responsable. El sacrificio del cordero de la ventera tiene lugar en el capítulo que viene a continuación, es decir, en el que abre la segunda parte del relato si seguimos

9. Claire J. Paolini (1986) realiza un estudio de los símbolos en la obra de Valle-Inclán desde el punto de vista místico y religioso. 
la estructura antes trazada. Tras aparecer el peregrino durante el sacrificio, el hijo de la ventera lo asesinará usando una hoz. Ádega, que se retira al establo cuando ve la figura del peregrino en el camino, presiente su muerte en un sueño cargado de notas simbólicas: la negrura, los cuervos, velos negros, camino solitario, lobos rabiosos, noche. Al despertarse sobresaltada y escuchar a la ventera decirle a su hijo que esconda la hoz, la pastora se lanza al campo «guiada del presentimiento, bajo la luna blanca, en la noche del monte sagrada de terrores» (pág.116).

En capítulos anteriores vemos esta hoz que acaba con la vida del peregrino y otras hoces que están descritas de la misma manera, apuntando un rasgo tétrico que tiene su explicación en el centro del relato. En el capítulo tres de la segunda estancia, se ve a dos zagales segando y el narrador resalta que «las hoces brillan con extraña ferocidad» (pág. 96), y con la misma «extraña ferocidad» (pág. 115) brilla la hoz del hijo de la ventera cuando ya ha llevado a cabo el sacrificio. Esta ferocidad con la que brilla la hoz es extraña porque por su uso común este rasgo no le corresponde, pero será con una hoz con la que se acabe con la vida del peregrino.

La sangre es otro símbolo de la muerte del mendicante. Así, en el capítulo cuarto de la segunda estancia, gente de mala calaña que duerme en la venta disputan. Los pastores con los que Ádega se encuentra en el monte refieren historias de terror que la asustan. Este ambiente violento y tétrico atemoriza a la pastora que espera que el peregrino la libere. En sus visiones idealizadas del peregrino, su figura se presenta llena de divinidad y sus pies descalzos sangran heridos por espinas. De cada gota de sangre brota un lirio. Los sonidos de trotar de caballos y los ladridos despiertan a Ádega de su sueño y vuelven a su memoria los relatos oscuros de los pastores que la llenan de pavor. Por la mañana encuentra removida la tierra y en la hierba se distinguen algunas salpicaduras de sangre. Esta presencia de la sangre y el sonido de ladridos que, como se sabe, son premonitorios de una muerte, se erigen como símbolos que adquieren su significado en el final de la vida del peregrino. En el capítulo siguiente, cuando la ventera y la pastora regresan a la venta con el rebaño de la fuente de San Gudián, donde las ovejas tenían que beber para romper el hechizo, encuentran al hijo de la ventera cubierto de sangre. Este tarda un tiempo en abrir la puerta y mientras tanto se oyen ladridos de perros. Cuando aparece el hijo, Ádega siente miedo, como si «un pájaro negro [...] extendiese sobre ella las alas» (pág.104). Lo que ha ocurrido es que ha desollado una cabra machorra. La cabra, como el lobo, es otro símbolo del mal y también se relaciona con el peregrino. Por tanto, este episodio tiene su paralelismo con el del asesinato del mendicante. 
Los símbolos del Bien y del Mal, aparejados a Ádega y al peregrino ${ }^{10}$ respectivamente, pueblan la narración. Aunque el mendicante es visto por la pastora como la figura de Nuestro Señor, su primera aparición está acompañada por el ladrido de los perros, signo de que va a ocurrir algo negativo, y atrae una tormenta. El portalón de la venta tiene el color de la sangre, signo este, el de la sangre, cuyo significado ya hemos aclarado. Las demás notas que acompañan al texto que abre el relato y que comienza con la visión del peregrino, va seguida por otros signos de tipo terrorífico, como el frío del invierno, la noche oscura, el recuerdo de una venta incendiada por cierto bandido, la historia sombría que va salmodiando el peregrino, el sonido del viento que parece el aullido de lobos, el balido de una cabra negra... En contraposición a esta figura que se acompaña de elementos negativos (la negra guedeja, su silueta oscura, etc.), Ádega posee rasgos de santa, su «voz estaba ungida de santidad» cuando descubre al ama que el peregrino es Nuestro Señor (pág. 90). Y otros elementos del texto también reciben este hálito religioso, como la oveja que muere, que tiene el «vellón de una oveja eucarística» (p. 90). El signo negativo y maléfico del peregrino se pone de manifiesto claramente en el momento en que Ádega admite que el diablo la ha visitado en su cama, cuando está en el Pazo de Brandeso, tras la visita del Abad que quiere exorcizarla: «huyó el Malo batiendo sus alas de murciélago» (pág. 149). La descripción de la relación carnal que quiere tener el diablo es paralela a la del peregrino en el establo en la primera parte del libro. En ambos fragmentos se pone de relieve un rasgo del personaje que denota su carácter negativo: las manos velludas. En contraposición a estas manos las de Ádega son «como dos palomas asustadas» (estancia primera, capítulo IV, pág. 85). En este momento, en el capítulo III de la última estancia, Ádega ve al peregrino como un ser maligno, se rompe la visión idealizada que tenía de él y la acción se centra, no ya en las visiones de la pastora, sino en la misa de las endemoniadas y el descubrimiento de su embarazo. Todavía en el capítulo final se resalta el carácter místico de la pastora pues las «violetas de sus pupilas estaban llenas de rocío como las flores del campo, y la luz de la mañana, que temblaba en ellas, parecía una oración» (págs. 153-154).

En la primera parte de Flor de santidad el eje temático principal es el doble juego entre el Bien y el Mal, por la presentación contrapuesta entre la pastora y el peregrino. En cambio, en la segunda parte el eje es el descubrimiento de la posesión demoníaca que sufre la pastora y la búsqueda de un nuevo hogar. En

10. Leonardo Romero Tobar (1999) hace un análisis de la figura del doble en el peregrino que demuestra de dónde toma el peregrino de la novela sus caracteres demoníacos. Este presenta rasgos de dos personajes distintos: del peregrino (personaje positivo) y de fray Ángel (personaje negativo), de la novela por entregas La Cara de Dios. 
la primera parte de la obra la gente, con excepción del hijo de la ventera, cree en las visiones que tiene Ádega, pero en la segunda parte, cuando anuncia que en su vientre lleva al hijo de Dios, sus visiones son rechazadas. En el capítulo IV de la cuarta estancia tiene lugar una conversación entre Ádega y la vieja que la acompaña al pazo de Brandeso, que interesa porque en ella rebaten la veracidad del libro de San Cidrián que permite descubrir tesoros escondidos. Mientras que la pastora cree lo que en él está escrito, la anciana lo niega. Se establece un juego de perspectivas que bien podría remitir al juego perspectivístico que ofrece la lectura de Flor de santidad. No obstante, el eje Bien/ Mal sigue siendo importante en la segunda parte. Baste citar la misa de las endemoniadas o la visión que Ádega tiene del Maligno. En esta segunda parte también sucede la total enajenación de Ádega, su búsqueda por los caminos y su acogida en un ambiente contrapuesto al de la venta. Resaltamos la idea de búsqueda por el constante símbolo del camino y porque esta búsqueda lleva a la protagonista a encontrar almas realmente caritativas y a salir del ambiente violento en el que vivía.

La obra no es, desde luego, un alegato contra la inocencia de las aldeanas que tienen visiones místicas, ni contra la superchería de los aldeanos, tampoco es una visión irónica de la Anunciación a la Virgen. La finalidad es puramente artística. El personaje Ádega es estéticamente bello y en contraposición a ella se presenta al peregrino, quien simboliza el Mal. El propósito es estético y no existe ninguna ironía o crítica encerrada, aunque el carácter abierto del final puede conducir a esta interpretación. Tal vez, hay un juego de perspectivas intrínseco para llevar al lector a esta interrogante. Flor de santidad es un poema en prosa en el que Valle-Inclán crea, a partir del recuerdo de lecturas, de cuentos de su infancia, de la rememoración de su tierra, una historia milenaria. El narrador mezcla su voz a la de otros narradores milenarios. Los sonidos que pueblan el relato son verdaderos símbolos: ladridos de perros, aullidos de lobos, repique de campanas, balidos de ovejas... Al lado de las notas acústicas hay que situar las visuales. El cromatismo es también simbólico: la oscuridad de la noche, el rojo de la sangre, las violetas que son los ojos. La maestría pictórica $^{11}$ y orquestal ${ }^{12}$ de la obra es indiscutible. En cuadros, en imágenes

11. Los rasgos pictóricos son innumerables. Recordamos, por ejemplo, al saludador, que aparece con una aureola de santidad. El saludador está «con el cordero en brazos, benigno y feliz como un abuelo de los tiempos patriarcales [...] Un rayo de sol atravesando los sarmientos de la parra ponían un nimbo de oro sobre la cabeza plateada del viejo» (pág. 99).

12. La crítica suele detenerse, en este sentido, en el análisis de la misa de las endemoniadas. Díaz-Plaja recalca su «grandiosidad wagneriana» (1965, pág. 177) y su «contextura sinfónica» (pág. 179). Bugliani (1986) muestra las coincidencias entre el episodio de

Anales, 22, 2010, pp. 49-63 
que se presentan como congeladas, se encierran los gestos que explican a un personaje, que definen su misma esencia. Hay una comunión íntima en este mundo milenario surgido de la pluma de Valle-Inclán, una armonía que deleita al lector, que deja en su pupila, como en la de Ádega, una nota de oración, un aire mítico. La lectura se abre, como una rosa, a otras interpretaciones. Ahí radica, quizá, la genialidad de Flor de santidad. Entre tanto sigue sonando el repique de las campanas a lo lejos y el artista se eterniza en su propia obra.

\section{BIBLIOGRAFÍA}

BUGLIANI, Américo. 1986. «Un palimpsesto valleinclaniano: páginas antológicas de Flor de santidad». Hispanística XX. Leer a Valle-Inclán, 4, Université de Dijon, págs. 73-90.

DíAz-Plaja, Guillermo. 1965. Las estéticas de Valle-Inclán, Madrid, Gredos.

DíEZ TABOADA, Ma Paz. 1995. «Ecos románticos en Flor de santidad de ValleInclán» en Valle-Inclán y su obra, Manuel Aznar Soler y Juan Rodríguez (eds.), Barcelona, págs. 295-305.

DOUGHERTY, Dru. 1997. «Valle-Inclán y el sincretismo literario. Flor de santidad», en Valle-Inclán y el fin de siglo, Universidad de Santiago de Compostela, págs. 341-354.

HoRMiGÓN, Juan Antonio. 2006. Valle-Inclán: Biografía cronológica y Epistolario, Publicaciones de la ADE, vol. III.

LAVAUD-FAGE, Eliane. 1991. La singladura narrativa de Valle-Inclán (1888-1915),

La Coruña, Fundación Pedro Barrié de la Maza.

- Los textos de Valle-Inclán: escritura y reescritura.

LAVAUD, Eliane et Jean-Marie. 1991. Valle-Inclán, un espagnol de la rupture, Actes Sud.

LÓPEZ-CASANOVA, Arcadio. 2006. «Introducción», en Ramón del VALLE-InClán, Flor de santidad y La media noche, Madrid, Espasa Calpe, págs. 9-63.

PAOLINI, Claire J. 1986. Valle-Inclán's Modernism. Use and Abuse of Religious and Mystical Symbolism, Valencia, Albatros Hispanofilia Ed.

PHILIPS, Allen W. 1970. «Flor de santidad: novela poemática de Valle-Inclán», en Homenaje a Sherman H. Eoff, Madrid, págs. 137-171.

Ramos, Rosa Alicia. 1991. Las narraciones breves de Ramón del Valle-Inclán, Madrid, Editorial Pliegos.

RISLEY, William R. 1992. «Hacia el simbolismo en la prosa de Valle-Inclán», en John P. Gabriele (ed.), Suma valleinclaniana, Barcelona, Anthropos, págs. 53-95.

Santa Baya de Cristamilde, en la misa de las endemoniadas, con la romería a Casalbordino en el Trionfo della Morte de Gabriele D’Annunzio. 
ROMERO TOBAR, Leonardo. 1999. «Flor de santidad: su proceso de redacción y la figura del doble». Analecta Malacitana. La Generación del 98. Relectura de textos, Universidad de Málaga, págs. 245-253.

SALPER, Roberta L. 1988. Valle-Inclán y su mundo: ideología y forma narrativa, Amsterdam, Editions Rodopi.

VAlle-InClÁn, Ramón María del. 1987. Artículos completos y otras páginas olvidadas, Javier Serrano Alonso (ed.), Madrid, Istmo.

- 1995. La lámpara maravillosa, Francisco Javier Blasco Pascual (ed.), Madrid, Espasa Calpe.

- 2006. Flor de santidad, Arcadio López-Casanova (ed.), Madrid, Espasa Calpe.

Fecha de recepción: 10 de septiembre de 2009.

Fecha de aprobación: 15 de noviembre de 2009. 